\title{
Contamination of some aquatic species with the organochlorine pesticide chlordecone in Martinique
}

\author{
Sophie Coat ${ }^{1, a}$, Gilles Bocquené ${ }^{2}$ and Eric Godard ${ }^{3}$ \\ 1 Petit Havre, 97190 Le Gosier, Guadeloupe Island, West Indies, France \\ 2 Ifremer, rue de l'Ile d'Yeu, BP 21105, 44311 Nantes Cedex 3, France \\ 3 Département Santé-Environnement DSDS de Guyane, 19 rue Schoelcher, BP 5001, 97305 Cayenne Cedex, France
}

Received 18 July 2005; Accepted 17 March 2006

\begin{abstract}
Martinique is a French overseas department whose economy relies heavily on agriculture. Organochlorine pesticides, mainly chlordecone, were used for banana cultivation to eradicate banana weevil over a period of 40 years. Chlordecone is chemically stable, and has a strong affinity for fatty tissues. It is therefore able to bioaccumulate in animals and thereby represent a threat to ecosystems and man. Soils from banana plantations in Martinique are heavily contaminated with chlordecone. Possible transfer of these molecules from agricultural watersheds to the aquatic environment and the organisms that live in it is feared. The hypothesis that ecosystems of Martinique might be highly contaminated with this organochlorine pesticide was investigated. Chlordecone levels were measured in various freshwater and marine species. Data show a heavy contamination of many carnivorous and detritivorous species (fish and prawns). Concentrations measured in wild or farmed tilapia are among the highest ever reported in the literature. Some coastal species (fish and lobster) were also found to be contaminated, although to a lesser extent. Given the biogeochemical behavior of chlordecone, the most likely route of contamination is food. Detected concentrations in marine organisms are below the tolerated limits established by authorities, however, the impact of other sources of exposure, namely, contaminated water and root vegetables, remains to be investigated.
\end{abstract}

Key words: Pesticides / Contamination / Chlordecone / Aquatic organisms / Food web / Caribbean Islands / W Atlantic

\section{Introduction}

Intensive banana farming practiced in tropical climates such as that of Martinique, leads to an increased vulnerability of crops to parasites and to the use of considerable amounts of pesticides. The use of organochlorines to eradicate insects such as the banana weevil first started in the nineteenfifties. Organochlorines are chemically stable lipophilic molecules which persist in the environment and are known as ecotoxic molecules. Molecules of this family have been prohibited in mainland France because of their ability to bioaccumulate. Authorization to sell chlordecone was withdrawn in 1990. As no other approved insecticide against banana weevil was available at the time, an exemption was granted that allowed the use of chlordecone $\left(\right.$ Kepone $\left.^{\circledR}\right)$ in the French West Indies until September 1993.

Chlordecone is still be detected in the different ecosystems of Martinique 10 years later (DSDS 2001). Investigations on chlordecone in the environment of Martinique first started

\footnotetext{
a Corresponding author: sophie.coat@univ-ag.fr
}

in June 1999. Chlordecone was first detected in streams and rivers that received water from agricultural watersheds located in the northern part of the island. During this study, the local Health Authority of Martinique identified chlordecone in root vegetables, such as Chinese cabbages, sweet potatoes and Carribean cabbages, grown in contaminated soils.

Organochlorines are hydrophobic and adsorb to the organic matter in the soil. Due to erosion of soil particles, desorption phenomena, slow solubilisation and infiltration processes, these compounds reach the groundwater table as well as many small streams that flow directly into the sea, which is never very far on the island of Martinique. The ensuing contamination of the aquatic environment threatens the organisms that live in it. Part of the fishery products in Martinique may therefore be contaminated.

This study focuses on contamination of freshwater and marine organisms which may contribute to increasing human population exposure to organochlorines in Martinique, and as such it is aimed at assessing the level of contamination of these organisms with chlordecone. 
Table 1. Characteristics of sampled species and sampling techniques.

\begin{tabular}{|c|c|c|c|}
\hline Scientific names & Common names & Characteristics & $\begin{array}{l}\text { Sampling } \\
\text { techniques }\end{array}$ \\
\hline Acanthurus bahianus & Surgeon fish & Coral reef fish, herbivorous & Fish pots \\
\hline Sparisoma sp. & Parrot fish & Coral reef fish, herbivorous & Fish pots, fishing nets \\
\hline Mugil sp. & Mullet & $\begin{array}{l}\text { Fish that lives on sandy bottoms, feeds } \\
\text { on small marine organisms, detritivorous, } \\
\text { omnivorous }\end{array}$ & Bottom gillnets \\
\hline Decapterus sp. & Mackerel scad & Pelagic fish, carnivorous & Fishing nets \\
\hline $\begin{array}{l}\text { Engraulidae, } \\
\text { Dussumieridae }\end{array}$ & $\begin{array}{l}\text { Anchovies } \\
\text { Blue sprat }\end{array}$ & Coastal fish. Juveniles of many species & Beach seines \\
\hline Anchoa lyolepis & Shortfinger anchovy & Coastal fish, plankton feeder & Beach seines \\
\hline Oreochromis sp. & Wild red tilapia & Brackish water fish, omnivorous & Line fishing \\
\hline Sciaenops ocellatus & Red drum & Marine fish, carnivorous & Farm-raised in floating cages \\
\hline Oreochromis sp. & Farmed red tilapia & Freshwater fish & Farm-raised in ponds \\
\hline Macrobrachium rosenbergii & Freshwater prawn & Freshwater shellfish & Farm-raised in ponds \\
\hline Panulirus argus & Spiny lobster & $\begin{array}{l}\text { Marine shellfish, necrophagous } \\
\text { and detritivorous }\end{array}$ & $\begin{array}{l}\text { Coastal cages } \\
\text { Trammel nets }\end{array}$ \\
\hline Lucina pectinata & Tropical clam & Bivalve mollusc & Collected in shallow waters \\
\hline Crassostrea rhizophorae & Mangrove oyster & Bivalve mollusc & Collected on mangrove roots \\
\hline Cardiidae & Cockles & Bivalve mollusc & Collected in shallow waters \\
\hline
\end{tabular}

\section{Materials and methods}

\section{Sampling}

Samplings were performed in fishing areas from which most of the local fish and shellfish consumed in Martinique comes from, as well as in inland streams and rivers which may have been exposed to organochlorines. Species were selected based on their feeding behaviors. Selected carnivorous fish species and detritivorous shellfish species were known to contribute to the biomagnification of chlordecone up the food chain. Other strict herbivorous species were also selected. The surgeon fish and the parrot fish were selected because they are ubiquitous, abundant, and able to ingest fine sediment. We selected filter-feeding bivalves in which contaminated particulate matter might have accumulated. Nine fish species, two shellfish species, and three bivalve species were collected in rivers, in the sea, and in fish farms in January and February 2002 (Table 1). A total of 260 animals were collected in the 27 sampling sites (Fig. 1). Numbers in bold correspond to the number of chlordecone-positive samples. Collected animals were kept frozen $\left(-80{ }^{\circ} \mathrm{C}\right)$ and shipped to mainland France on dry ice for analysis. Samples from animals of the same species collected at once at the same site were pooled. A total of $9950-\mathrm{g}$ samples of flesh were thus obtained, each sample being a pool of 10 individuals.

Chlordecone levels were measured in the dorsal muscle in fish, in the abdominal muscle in shellfish, and in total flesh in molluscs.

\section{Chemical analysis}

Sample processing (extraction and purification) and measurement of chlordecone pesticide concentrations were carried

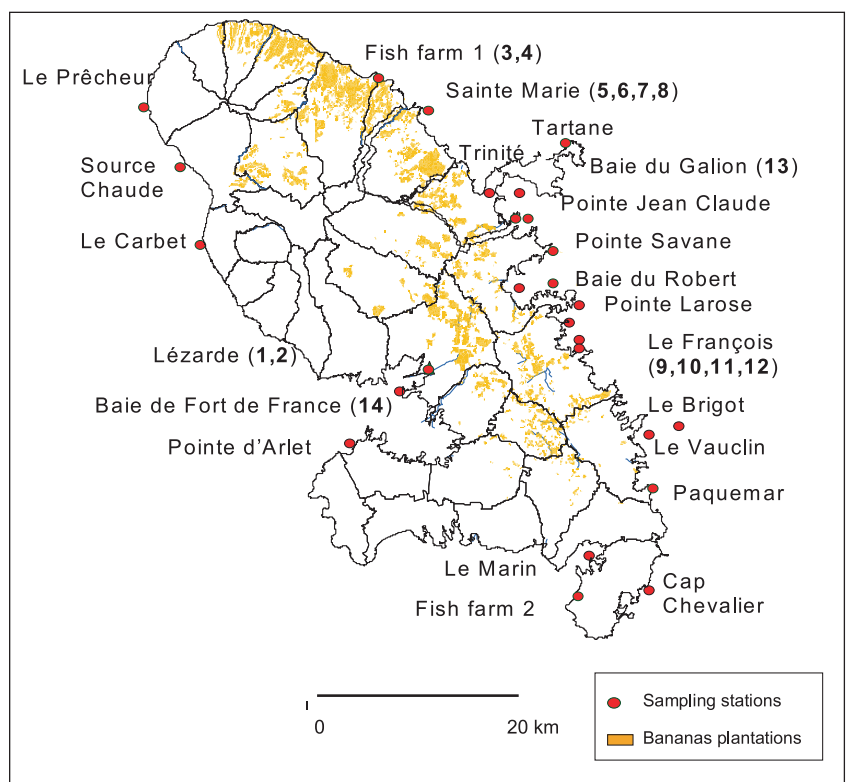

Fig. 1. Sampling stations (numbers in brackets correspond to samples where chlordecone levels were positive) in Martinique, West Indies, Caribbean Islands.

out at the Laboratoire Départemental d'Analyses de la Drome (Valence).

Cryogenic centrifugation extraction were NF EN 1528compliant (European Reference Norme for the analysis of organochlorine compounds). Solid phase extractions were carried out according to the AFSSA-LERHQA-CENPOP/01 method developed by l'Agence Française de Sécurité Sanitaire des Aliments (Laboratory for Studies \& Research on Hygiene 
Table 2. Chlordecone levels in a number of aquatic animal species. Results are given in $\mu \mathrm{g} \mathrm{kg}^{-1}$ wet weight on a pool of 10 individuals.

\begin{tabular}{|c|c|c|c|c|}
\hline $\mathbf{N}^{\circ}$ & Sampling site & Species & $\begin{array}{l}\text { Chlordecone } \\
\left(\mu \mathrm{kg}^{-1}\right)\end{array}$ & Comments \\
\hline 1 & \multirow[t]{2}{*}{ Lézarde } & \multirow[t]{2}{*}{ Wild red tilapia } & 386 & \multirow{2}{*}{$\begin{array}{l}\text { This river runs through banana } \\
\text { plantations. }\end{array}$} \\
\hline 2 & & & 196 & \\
\hline 3 & \multirow[t]{2}{*}{ Fish farm 1} & Farmed red tilapia & 132 & \multirow{2}{*}{$\begin{array}{l}\text { Fish farm located on polluted grounds } \\
\text { in the Northeast of the island. }\end{array}$} \\
\hline 4 & & Freshwater prawn & 23 & \\
\hline 5 & \multirow[t]{4}{*}{ Sainte-Marie } & \multirow[t]{2}{*}{ Mackerel scad } & 3 & \multirow{4}{*}{$\begin{array}{l}\text { These fish migrate upstream to the } \\
\text { mouth of the river in the Northeast of } \\
\text { the island. }\end{array}$} \\
\hline 6 & & & 4 & \\
\hline 7 & & \multirow[t]{2}{*}{ Shortfinger anchovy } & 7 & \\
\hline 8 & & & 4 & \\
\hline 9 & \multirow{4}{*}{ Baie du François } & \multirow[t]{3}{*}{ Spiny lobster } & 20 & \multirow{6}{*}{ Enclosed areas (bays, inlets). } \\
\hline 10 & & & 31 & \\
\hline 11 & & & 13 & \\
\hline 12 & & Surgeon fish & 4.1 & \\
\hline 13 & Baie du Galion & Spiny lobster & 10 & \\
\hline 14 & Baie de Fort-de-France & Surgeon fish & 1.2 & \\
\hline
\end{tabular}

\begin{tabular}{|l|l|l|l|l|}
\hline Freshwater & & Brackish water & & Seawater \\
\hline
\end{tabular}

\& Quality of Foods). This method follows a four-step procedure:

1. Fats are extracted from samples with hexane.

2. Pesticides are extracted from fats by acetonitrile-hexane partitioning.

3. Purification, i.e., elimination of interfering substances, is achieved using C18 and Florisil solid phase extraction cartridges.

4. Levels of organochlorines are measured by gaschromatography (GC) with electron capture detector (ECD). GC conditions were as follows: DB5 column, $60 \mathrm{~m}$ lenght, $0.25 \mathrm{~mm}$ diameter. The $\mathrm{GC}$ oven was held at $60{ }^{\circ} \mathrm{C}$ for $4 \mathrm{~min}$, then ramped to $200{ }^{\circ} \mathrm{C}$ at $20{ }^{\circ} \mathrm{C} \mathrm{min}{ }^{-1}$, held at $200{ }^{\circ} \mathrm{C}$ for $20 \mathrm{~min}$, then ramped to $320{ }^{\circ} \mathrm{C}$ at $5{ }^{\circ} \mathrm{C} \mathrm{min}{ }^{-1}$ and finally held at $320{ }^{\circ} \mathrm{C}$ for $10 \mathrm{~min}$. The GC inlet was operated in splitless mode at $250{ }^{\circ} \mathrm{C}$, with a $1 \mu \mathrm{l}$ injection volume. The detector was held at $300{ }^{\circ} \mathrm{C}$. Confirmation was undertaken using a DB1701 column, $60 \mathrm{~m}$ lenght, $0.25 \mathrm{~mm}$ diameter. Here the GC oven was held at $60{ }^{\circ} \mathrm{C}$ for $2 \mathrm{~min}$, then ramped to $200{ }^{\circ} \mathrm{C}$ at $20{ }^{\circ} \mathrm{C} \mathrm{min}^{-1}$, held at $200{ }^{\circ} \mathrm{C}$ for $20 \mathrm{~min}$, then ramped to $280{ }^{\circ} \mathrm{C}$ at $5^{\circ} \mathrm{C} \mathrm{min}{ }^{-1}$ and finally held at $280{ }^{\circ} \mathrm{C}$ for $16 \mathrm{~min}$. Inlet and detector conditions were as above. Detection limit was $1 \mu \mathrm{g} \mathrm{kg}^{-1}$ (wet weight).

\section{Quality assurance}

The laboratory involved in the chlordecone analysis is ISO 17025-compliant (ISO 17025 is the equivalent of ISO 9000 for calibration and testing laboratories) and have been accredited by the French Accreditation Committee (COFRAC). Quality assurance testing included the analysis of blanks, assessment of recoveries and reproducibilities and accuracy of the data relative to standard reference materials. The laboratory is also approved for official control by the French Ministry of the sustainable Environment (MEDD): approval No. 8, organic contaminant for brackish and salt waters including organochlorine compounds. The performances for recovery of chlordecone were $>80 \%$.

\section{Results}

Results are expressed as micrograms of chlordecone per kilogram of flesh (wet weight). Fourteen of the 99 samples analyzed were found to contain chlordecone. Positive results are presented in Table 2 .

The highest chlordecone concentrations were detected in wild red tilapia samples collected in the Lézarde River, which runs through banana plantations before flowing into the Bay of Fort-de-France. Chlordecone concentrations of 386 and $196 \mu \mathrm{g} \mathrm{kg}^{-1}$ of flesh were detected in 2 sample composites of wild red tilapia collected at the Lézarde River sampling site. Both farmed-raised tilapia and prawn from freshwater ponds located in the Northeast part of the island were also found to be contaminated with chlordecone. Chlordecone levels were $132 \mu \mathrm{g} \mathrm{kg}^{-1}$ and $23 \mu \mathrm{g} \mathrm{kg}^{-1}$ in tilapia and prawn, respectively.

Certain beach-seined marine fish and shellfish species were also contaminated with chlordecone: levels ranged from 3 to $7 \mu \mathrm{g} \mathrm{kg}^{-1}$ in 4 of 8 anchovy and mackerel scad samples collected at the Sainte Marie sampling site, in the Northeastern section of the island. Chlordecone concentrations measured in 4 spiny lobster and 2 surgeon fish samples from various sampling sites were the following: 10, 13, 20, and $31 \mu \mathrm{g} \mathrm{kg}^{-1}$ in spiny lobster samples, 4.1 and $1.2 \mu \mathrm{g} \mathrm{kg}^{-1}$ in surgeon fish samples. 
Table 3. Concentrations in organochlorine pesticides in the aquatic fauna of various regions worldwide $\left(\mu \mathrm{g} \mathrm{kg}^{-1}\right.$ wet weight).

\begin{tabular}{|c|c|c|c|c|c|}
\hline Location, date & Species & \multicolumn{3}{|c|}{$\begin{array}{l}\text { Predominant organochlorines detected } \\
\text { and mean concentration range }\end{array}$} & Reference \\
\hline $\begin{array}{l}\text { Martinique } \\
2002\end{array}$ & $\begin{array}{l}\text { wild tilapia } \\
\text { farmed tilapia }\end{array}$ & \multicolumn{2}{|c|}{$\begin{array}{l}\text { chlordecone: } 196-386 \\
\text { chlordecone: } 132\end{array}$} & $\beta \mathrm{HCH}: \varnothing$ & This publication \\
\hline \multirow{5}{*}{$\begin{array}{l}\text { Virginia, USA } \\
1977\end{array}$} & freshwater fish & \multicolumn{3}{|c|}{ chlordecone: $\mathbf{2 5 0 0}$} & \multirow{5}{*}{$\begin{array}{l}\text { Nichols (1990) in } \\
\text { ATSDR (1995) }\end{array}$} \\
\hline & phytoplankton & \multicolumn{3}{|c|}{ chlordecone: 1300} & \\
\hline & zooplankton & \multicolumn{3}{|c|}{ chlordecone: $\mathbf{4 8 0 0}$} & \\
\hline & migrating fish & \multicolumn{3}{|c|}{ chlordecone: $\mathbf{4 0 0}$} & \\
\hline & benthic molluscs & \multicolumn{3}{|c|}{ chlordecone: 1500} & \\
\hline Hawaii, 2001 & various fish species & $\begin{array}{l}\text { dieldrin: } \\
50-1700\end{array}$ & $\begin{array}{l}\text { cis-chlordane: } \\
17-460\end{array}$ & $\begin{array}{l}\text { p, p'-DDE: } \\
\mathbf{4 - 1 8 0}\end{array}$ & $\begin{array}{l}\text { Brasher and Wolff } \\
(2003)\end{array}$ \\
\hline $\begin{array}{l}\text { Georgia, USA, } \\
1997\end{array}$ & $\begin{array}{l}\text { Silver sea trout } \\
\text { (Cynoscion nothus) }\end{array}$ & $\begin{array}{l}\gamma \mathrm{HCH}: \\
0.8\end{array}$ & $\begin{array}{l}\text { cis-chlordane: } \\
7.08\end{array}$ & $\begin{array}{l}\text { p, p'-DDE: } \\
1.03\end{array}$ & $\begin{array}{l}\text { Loganathan et al. } \\
\text { (2001) }\end{array}$ \\
\hline Jamaica, 1983 & Shrimps & $\begin{array}{l}\text { dieldrin: } \\
\mathbf{0 . 4 2 7 - 5 . 5 9} \\
\end{array}$ & $\begin{array}{l}\gamma \mathrm{HCH}: \\
2.90\end{array}$ & $\begin{array}{l}\text { DDE: } \\
\text { 0.344-14.57 }\end{array}$ & $\begin{array}{l}\text { Mansingh et al. } \\
(2000)\end{array}$ \\
\hline $\begin{array}{l}\text { Lake Ontario, USA, } \\
1992\end{array}$ & $\begin{array}{l}\text { Coho salmon } \\
\text { (Oncorhynchus } \\
\text { kisutch) }\end{array}$ & $\begin{array}{l}\text { mirex: } \\
240\end{array}$ & & & $\begin{array}{l}\text { Makarevicz et al. } \\
(2003)\end{array}$ \\
\hline Jamaica, 1992 & Aquatic fauna & $\begin{array}{l}\text { dieldrin: } \\
\varnothing\end{array}$ & $\begin{array}{l}\text { a-endosulfan: } \\
68.5-110.6\end{array}$ & $\begin{array}{l}\beta \text {-endosulfan: } \\
4.31-53.7\end{array}$ & $\begin{array}{l}\text { Robinson and } \\
\text { Mansingh (1999) }\end{array}$ \\
\hline Mexico, 1996 & Shrimp & $\begin{array}{l}\delta \mathrm{HCH}: \\
48.8-127\end{array}$ & $\begin{array}{l}\text { lindane: } \\
\varnothing-132\end{array}$ & $\begin{array}{l}\text { DDE: } \\
19-29\end{array}$ & $\begin{array}{l}\text { Osuna-Flores and } \\
\text { Riva (2001) }\end{array}$ \\
\hline Italy, 1997 & $\begin{array}{l}\text { Mackerel } \\
\text { (Scomber scombrus) }\end{array}$ & $\begin{array}{l}\text { dieldrin: } \\
0.63-1.17\end{array}$ & $\begin{array}{l}\gamma \mathrm{HCH}: \\
0.20-0.83\end{array}$ & $\begin{array}{l}\text { p, p'-DDE: } \\
\text { 15.32-25.18 }\end{array}$ & $\begin{array}{l}\text { Stefanelli et al. } \\
(2002)\end{array}$ \\
\hline India, 1999 & various fish species & $\begin{array}{l}\gamma \mathrm{HCH}: \\
1-3\end{array}$ & $\begin{array}{l}\text { total } \mathrm{HCH}: \\
1-6\end{array}$ & $\begin{array}{l}\text { DDT: } \\
13-55\end{array}$ & $\begin{array}{l}\text { Sarkar et al. } \\
(2003)\end{array}$ \\
\hline Egypt, 2001 & $\begin{array}{l}\text { Mullet } \\
\text { (Mugil spp.) }\end{array}$ & $\begin{array}{l}\text { dieldrine: } \\
\text { 5.3-15.1 }\end{array}$ & $\begin{array}{l}\text { lindane: } \\
5.9-14.3\end{array}$ & \begin{tabular}{l|l}
$5.9-14.3$ & $9.3-33.7$ \\
\end{tabular} & $\begin{array}{l}\text { El Nemr and } \\
\text { Abd-Allah (2003) }\end{array}$ \\
\hline Brazil, 1999 & various fish species & $\begin{array}{l}\text { p, p'-DDE: } \\
\varnothing-19.7\end{array}$ & & & Da Silva et al. (2003) \\
\hline Taiwan, 1999 & various fish species & $\begin{array}{l}\text { p,p'-DDE: } \\
95.38-99.11\end{array}$ & \multicolumn{2}{|l|}{$\begin{array}{l}\text { p, p'-DDD: } \\
\mathbf{8 0 . 0 1 - 4 8 8 . 3 3}\end{array}$} & Yuan et al. (2004) \\
\hline
\end{tabular}

$\varnothing$ : below detection limit

$\mathrm{HCH}$ : hexachlorocyclohexane

DDE and DDD: DDT metabolites

As opposed to animals that were collected in enclosed or coastal areas, or near estuaries, fish collected offshore (mackerel, parrot fish, and farmed red drum) had no detectable chlordecone (data $<$ detection limit).

\section{Discussion}

Analyses revealed the presence of chlordecone in a number of aquatic animal species. Half of the 14 species studied (5 of 9 fish species, 2 of 2 shellfish species) were contaminated. Chlordecone was also detected in coastal and coral reef fish species, such as the surgeon-fish, and in spiny lobster. No chlordecone was, however, found in filter-feeding bivalves or fish collected offshore, such as the red drum.

This study shows that the highest contamination levels are found in wild and farm-raised tilapia (carnivores) and crustaceans (detritivores). Great variations are observed among the different species. The highest levels are detected in wild tilapia (386 and $196 \mu \mathrm{g} \mathrm{kg}^{-1}$ ), farm-raised tilapia (132 $\mu \mathrm{g} \mathrm{kg}^{-1}$ ) and, although to a lesser extent, freshwater prawn $\left(23 \mu \mathrm{g} \mathrm{kg}^{-1}\right)$ and spiny lobster $(31,20$, and $13 \mu \mathrm{g} \mathrm{kg}^{-1}$ ). Contamination by pesticides was recently observed for other organochlorines detected in fish species collected in Egypt. Ten organochlorines (HCB, lindane, heptachlor, heptachlor epoxide, dieldrin, p,p'-DDT, p,p'-DDE, p,p'-DDD, toxaphene, chlordane) were detected in the following fish species (from the most to the least contaminated): the mullet (Mugil cephalus), sea bream (Sparus auratus), bogue (Boops boops), and sand sole (Pegusa lascaris) (El Nemr and Abd-Allah 2004). In the Adriatic Sea, the highest concentration in mackerel (Scomber scombrus) was $25.18 \mu \mathrm{g} \mathrm{DDE} \mathrm{kg}^{-1}$ wet weight (Stefanelli et al. 2004). In a study conducted in Tanzania, reported organochlorine levels detected in a tilapia species (Tilapia jipe) were $20.4 \mu \mathrm{g}$ of total DDT (p,p'-DDT, p,p'-DDE, and p,p'-DDD) per kg fresh weight 
(Mwevura et al. 2002). Variation in the levels of organochlorine pesticide residues found in aquatic species is multifactorial. The nature and solubility of these molecules, the degree and duration of exposure, the type of diet, as well as the animal's lipid load are influential factors. The type of diet and lipid load play an especially important role in the accumulation of organochlorine pesticides. Due to its poor solubility in water and strong affinity for organic matter $\left(\log K_{\text {ow }}=4.5\right)$, chlordecone is preferentially found in sediment rather than in the water column, and as such, mostly accumulates in detritivorous and carnivorous species. Studies conducted in marine fish species have reported BCF-values of 16000 in the fathead minnow (WHO-IPCS 1984). Zhou et al. (1999) studied contamination of tilapia with chlorinated compounds in their laboratory. They showed that ingestion of sediment and/or contact with chlorinated particles were the predominant pathways of sediment-sorbed accumulation in tilapia.

Our results suggest that contamination is generally less important in herbivorous fish species. Chlordecone levels detected in the surgeon fish, which is a strict herbivore, were very low $\left(1.2-4.1 \mu \mathrm{g} \mathrm{kg}^{-1}\right)$. A study of contamination of the common carp (Cyprinus carpio), also an herbivor, with lindane, alpha-chlordane, gamma-chlordane, and 4,4'-DDE, in its natural habitat was conducted in Kansas by Eaton and Lydy. These authors reported that the mean total organochlorine concentration of all fish was $9.32 \pm 3.07 \mu \mathrm{g} \mathrm{kg}^{-1}$ (Eaton and Lydy 2000).

In Martinique, contamination of animals in farm ponds may be due to the presence of contaminated clay soils and suspended particulate matter present in water from an upstream source, or else from the contaminated microflora and microfauna present in fish feeds. Analyses done in 2001 by the DSDS on soil samples from banana plantations that had been treated for long periods of time, revealed the presence of chlordecone in all of them. Levels reaching $5000 \mu \mathrm{g} \mathrm{kg}^{-1}$ of chlordecone were measured in soils of the Gradis farm, located near the River Rouge, in August 1999, and levels up to $13000 \mu \mathrm{g} \mathrm{kg}^{-1}$ dry weight were recorded in hydromorphic soils, in a parcel of land along the north Atlantic coast (Bellec and Godard 2002). These contaminated soils constitute decades worth of chlordecone "supplies". River water analyses carried out by the DSDS (DSDS 2001) between June 1999 and June 2001 revealed an average chlordecone concentration of $0.3 \mu \mathrm{g} \mathrm{L}^{-1}$ in the Capot River. In some samples, values even reached $1 \mu \mathrm{g} \mathrm{L}^{-1}$. A recent study of contamination of water in estuaries of Martinique showed that chlordecone was mainly found in suspended particulate matter and sediment. It was found in sediment samples of the Lorrain $\left(1.44 \mu \mathrm{g} \mathrm{kg}^{-1}\right)$, François (4.38 $\left.\mu \mathrm{g} \mathrm{kg}^{-1}\right)$, and Lézarde $\left(9.31 \mu \mathrm{g} \mathrm{kg}^{-1}\right)$ Rivers, as well as in suspended particulate matter samples collected in the plume of the François $\left(4.57 \mu \mathrm{g} \mathrm{kg}^{-1}\right)$, Galion $\left(3.52 \mu \mathrm{g} \mathrm{kg}^{-1}\right)$, Lézarde $\left(9.45 \mu \mathrm{g} \mathrm{kg}^{-1}\right.$ ), and Cacao (5.22 $\mu \mathrm{g} \mathrm{kg}^{-1}$ ) Rivers (Bocquené and Franco 2005).

It is interesting to note that farmed red drum reared in sea cages and fed with imported synthetic feeds were not contaminated. This observation supports the strong probability that a trophic transfer of organochlorine contaminants occurs in the environment.

Organochlorines have also been massively used for long periods of time in many other regions around the world.
Many studies now report on the ensuing contamination of aquatic systems. Some data regarding concentrations of various organochlorines in aquatic species are presented in Table 3.

The presence of organochlorine insecticides in the aquatic fauna is ubiquitous and can even be found in isolated regions. For example, Sarkar et al. (2003) reported the presence of $\gamma \mathrm{HCH}$ and DDT in two freshwater fish species, the putitor mahseer (Tor putitora) and the snow trout (Schizothorax richardsonii), in the Himalaya.

The highest levels of chlordecone in the aquatic fauna were detected in the State of Virginia, USA, near a chlordecone production plant (Nichols 1990 in Agency for Toxic Substances and Disease Registry: ATSDR 1995). In 1977, two years after the plant had closed, chlordecone concentration was monitored in various species living in the James River. Chlordecone levels reached $2500 \mu \mathrm{g} \mathrm{kg}^{-1}$ in freshwater fish, and the highest levels, i.e., $4800 \mu \mathrm{g} \mathrm{kg}^{-1}$, were recorded in zooplankton. In this particular case, contamination of the James River and neighbouring streams was not due to diffuse pollution related to an extensive use of this molecule in neighbouring cultures but rather to industrial negligence. Chlordecone levels measured in Martinique are among the highest worldwide after those recorded in Virginia. They are much higher than the following average concentrations of total DDT (DDT and metabolites, p,p'- DDE and p,p'- DDD) measured along the European coasts: $2.42,8.8$, and $11.32 \mu \mathrm{g} \mathrm{kg}^{-1}$ wet weight in the common sole (Solea solea), mackerel (Scomber scombrus), and estuarian flounder (Platichtys flesus), respectively, along the Atlantic coast (Cossa et al. 1990), $25.00 \mu \mathrm{g} \mathrm{kg}^{-1}$ in mackerel from the Adriatic Sea (Stefanelli et al. 2004), and $38.4 \pm 17 \mathrm{~g} \mathrm{~kg}^{-1}$ wet weight in flounder from Garston in the inner Mersey Estuary in UK (Leah et al. 1997).

Given the biogeochemical behaviour of these contaminants, the disappearance of these molecules from the environment may take centuries (Makarewicz 2003).

Consumption of fish in Martinique, which reaches 16000 tons a year, is one of the highest in the world in proportion to the number of inhabitants. Local production (fishing and aquaculture), however, accounts for approximately 6000 tons (INSEE 2002). Fresh fish, which mainly comes from traditional fishing, is distributed in a number of harbours.

Only part of the population of Martinique consumes fish distributed by coastal fishing villages. Therefore significant exposure to the pesticides that have been used in banana plantations through consumption of aquatic organisms only concerns that part of the population. Most of the fish distributed by these coastal fishing communities is, however, caught offshore and unlikely to be contaminated. Exposure to chlordecone is therefore rather associated with consumption of organisms from enclosed bays, rivers, and farm ponds.

A correlation between lipid load and concentration in organochlorines is usually observed in fish and molluscs (Mehdaoui et al. 2000; Das et al. 2002). Further investigation in species with a higher lipid load, such as Clupeidae (herring, sprat, sardine) or tunas (although these are rather pelagic species that live away from contaminated coastal areas) is thus warranted. The toxicity reference value, the maximum concentration of organochlorine compound residues tolerated in 
food, determined by the Institut Français National de Veille Sanitaire (INVS) is equivalent to that established by American Authorities, i.e., $0.5 \mu \mathrm{g} \mathrm{kg}^{-1} \mathrm{~d}^{-1}$, or $30 \mu \mathrm{g} \mathrm{d}^{-1}$ for a $60 \mathrm{~kg}$ adult (Bonvalot and Dor 2004). In order to reach the acceptable daily intake (ADI), an individual must consume $77 \mathrm{~g}$ of wild tilapia, $227 \mathrm{~g}$ of farmed tilapia, $1 \mathrm{~kg}$ of spiny lobster, or $1.3 \mathrm{~kg}$ of prawn from contaminated areas every day.

Chlordecone concentrations of $0.3 \mathrm{mg} \mathrm{kg}^{-1}$ of edible fish tissue and $0.4 \mathrm{mg} \mathrm{kg}^{-1}$ of crab flesh were determined by the US Food and Drug Administration (FDA) as the intervention limit, which gives some leeway before consumption of these aquatic products is prohibited.

Organochlorines also bioaccumulate in humans. Organochlorine pesticides were detected in fatty tissue samples of Martinique residents (Martin 1973). Mirex, a compound related to chlordecone, also used as an insecticide, was found in the breast milk of Canadian women whose diet essentially consisted of fish from Lake Ontario (Makarewicz et al. 2002). Organochlorine pesticides were also detected in the serum of Japanese individuals. Average concentration of beta-hexachlorocyclohexane $(\beta \mathrm{HCH})$, hexachlorobenzene (HCB), and total DDT (p,p'-DDE and p,p'-DDT) were respectively, $0.50 \mathrm{ng} \mathrm{ml}^{-1}, 0.20 \mathrm{ng} \mathrm{ml}^{-1}$, and $5 \mathrm{ng} \mathrm{ml}^{-1}$ (Hanaoka 2002).

It is important to keep in mind that aquatic organisms are not the only source of intake for organochlorines in Martinique but one of the major routes of exposure. The above ADI values should therefore also take into account intake levels associated with the consumption of water and other contaminated foods, such as root vegetables grown on lands contaminated by banana plantation run-offs.

\section{Conclusion}

Although the use of chlordecone has been prohibited for over 10 years, high levels of chlordecone are still detectable in a number of aquatic species of Martinique (up to $386 \mu \mathrm{g} \mathrm{kg}^{-1}$ chlordecone in locally consumed tilapia). Measured values are impressively high compared to those reported for other regions around the world. Detected concentrations in marine organisms are below the tolerated limits established by authorities; however, the impact of other sources of exposure, namely, contaminated water and root vegetables, remains to be investigated.

Acknowledgements. Financial support from the DSDS of Martinique is gratefully acknowledged.

\section{References}

Agency for Toxic Substances and Disease Registry (ATSDR), 1995, Toxicological profile for mirex and chlordecone. Atlanta, GA: US Department of Health and Human Services, Public Health Service.

Bellec S., Godard E., 2002, Contamination par les produits phytosanitaires organochlorés en Martinique. Caractérisation de l'exposition des populations. DSDS de la Martinique, Service Santé-Environnement, 36 p.
Bocquené G., Franco A., 2005, Pesticide contamination of the coastline of Martinique. Mar. Pollut. Bull. 51, 612-619.

Bonvalot N., Dor F., 2004, Insecticides organochlorés aux Antilles : identification des dangers et valeurs toxicologiques de référence. État des connaissances. INVS, département santé environnement, Saint Maurice, France.

Brasher A.M.D., Wolff R.H., 2004, Relations between land use and organochlorine pesticides, PCBs, and semi-volatile compounds in streambed sediment and fish on the Island of Oahu, Hawaii. Arch. Environ. Contam. Toxicol. 46, 385-398.

Cossa D., Auger D., Averty B., Luçon M., Masselin P., Noel J., Sanjuan J., 1990, Niveau de concentration en métaux, métalloïdes et composés organochlorés dans les produits de la pêche côtière française. Ifremer, Nantes, $60 \mathrm{p}$.

Das B., Khan Y.S., Das P., Shaheen S.M., 2002, Organochlorine pesticide residues in catfish, Tachysurus thalassinus (Ruppell, 1835), from the South Patches of the Bay of Bengal. Environ. Pollut. 120, 255-259.

Da Silva A.M.F., Lemes V.R.R., Barretto H.H.C., Oliveira E.S., de Alleluia I.B., Paumgartten F.J.R. , 2003, Polychlorinated biphenyls and organochlorine pesticides in edible fish species and dolphins from Guanabara Bay, Rio de Janeiro, Brazil. Bull. Environ. Contam. Toxicol. 70, 1151-1157.

DSDS, 2001, Pesticides et alimentation en eau potable en Martinique. État des lieux et position sanitaire. Bilan actualisé en octobre 2001. Direction de la Santé et du développement Social de la Martinique. Fort-de-France. Martinique Island. France.

Eaton H.J., Lydy M.J., 2000, Assessment of water quality in Wichita, Kansas, using an index of biotic integrity and analysis of bed sediment and fish tissue for organochlorine insecticides. Arch. Environ. Contam. Toxicol. 39, 531-540.

El Nemr A., Abd-Allah A.M.A., 2004, Organochlorine contamination in some marketable fish in Egypt. Chemosphere 54, 1401-1406.

Hanaoka T., Takahashi Y., Kobayashi M., Sasaki S., Usuda M., Okubo S., Hayashi M., Tsugane S., 2002, Residuals of betahexachlorocyclohexane, dichlorodiphenyltrichloroethane, and hexachlorobenzene in serum, and relations with consumption of dietary components in rural residents in Japan. Sci. Total Environ. Mar. 8, 286, 119-27.

INSEE, 2002, Tableaux économiques régionaux de la Martinique. Pointe-à-Pitre, $152 \mathrm{p}$.

Leah R.T., Johnson M.S., Conner L., Levene C.F., 1997, DDT group compounds in fish and shellfish from the Mersey Estuary and Liverpool Bay. Environ. Toxicol. Water Quality 12, 223-229.

Loganathan B.G., et al., 2001, Persistent organochlorine concentrations in sediment and fish from atlantic coastal and brakish waters off Savannah, georgia, USA. Mar. Pollut. Bull. 42, 246-250.

Makarewicz J.C., Damaske E., Lewis T.W., Merner M., 2003, Trend analysis reveals a recent reduction in mirex concentrations in Coho (Oncorhynchus kisutch) and Chinook (O. tshawytscha) salmon from Lake Ontario. Environ. Sci. Technol. 37, 1521-1527.

Mansingh A., Robinson D.E., Henry C., Lawrence V., 2000, Pesticide contamination of Jamaican environment. II. Insecticide residues in the rivers and shrimps of Rio Cobre Basin, 1982-1996. Environ. Monitoring Assess. 63, 459-480.

Martin M., 1973. Les pesticides organochlorés. Recherches des résidus dans le tissu adipeux humain et animal en Martinique. $\mathrm{PhD}$ Medical Thesis. INRA Antilles-Guyane.

Mehdaoui O., Fekhaoui M., Descoins C., 2000, Accumulation and biomagnification of organochlorine insecticides in molluscs and fish of the Moulay Bouselham lagoon, Morocco. Santé. 2000 Nov-Dec. 10, 373-379. 
Mwevura H., Othman O.C., Mhehe G.L., 2002, Organochlorine pesticide residues in sediments and biota from the coastal area of Dar es Salaam city, Tanzania. Mar. Pollut. Bull. 45, 262-267.

Nichols M.M., 1990, Sedimentologic fate and cycling of Kepone in an estuarine system: exemple from the James River estuary. Sci. Total Environ. 97/98, 407-440.

Osuna-Flores I., Riva M.C., 2002, Organochlorine pesticide residue concentrations in shrimps, sediments, and water surface from Bay of Ohuira, Topolobampo, Sinaloa, Mexico. Bull. Environ. Contam. Toxicol. 68, 532-539.

Robinson D.E., Mansingh A., 1999, Insecticide contamination of Jamaican environment. IV. Transport of residues from coffe plantations in the Blue Mountains to coastal waters in eastern Jamaica. Environ. Monitoring Assess. 54, 125-141.

Sarkar U.K., Basheer V.S., Singh A.K., Srivastava S.M., 2003, Organochlorine pesticide residues in water and fish samples: first report from rivers and streams of Kumaon Himalayan Region, India. Bull. Environ. Contam. Toxicol. 70, 485-493.

Stefanelli P., et al., 2004, Estimation of intake of organochlorine pesticides and chlorobiphenyls through edible fishes from the Italian Adriatic Sea during 1997. Food Control 15, 27-38.

WHO-IPCS, 1984, Environmental Health Criteria. No. 43. Chlordecone. Genova. World Health Organization.

Yuan Y.C., Yuan Y.K., Chen H.C., 2004, Accumulation of organochlorine pesticides in marine fishes coast of Taoyuan in Taiwan. Bull. Environ. Contam. Toxicol. 73, 306-311.

Zhou H.Y., Cheung R.Y.H., Wong M.H., 1999, Residues of Organochlorines in Sediments and Tilapia Collected from Inland Water Systems of Hong Kong. Arch. Environ. Contam. Toxicol. $36,424-431$. 